【論 文】

\title{
水平噴流による洗掘に関する研究 \\ STUDIES ON THE SCOUR FROM SUBMERGED PLANE JET
}

\section{1. 緒言}

局所洗掘は各断面を通過する移動砂量の場所的変化に 起因するものであるが，一般に洗掘の進行に伴って洗掘 面に沿う流れが大きく変化し，その変化した流れによっ て洗掘されていくように, 洗掘の進行とそれに伴う流れ の変化とが密接に関連するきわめて複雑な現象である.

水平噴流による洗掘は局所洗掘に関する基礎的なもの の一つとして古くから研究されているが，理論的なもの は意外に少なく，河床砂の連続の式を用いてかなりお拉 まかな考察を行った Lavrsen の研究 ${ }^{1)}$, 壁面噴流におけ

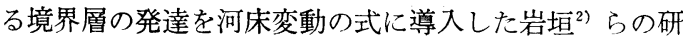
究，および壁面噴流の特性に加えて非平衡状態の流砂関 数を用いて考察した土屋の研究 ${ }^{3)}$ が代表的なものとして あげられる．これらの理論は平面に沿ら噴出流の流れに よって洗掘機構を考察した初期洗掘に関するもので, 洗 掘の進行に伴う流れの変化を考慮した研究はみあたらな い.

本研究においては，河床変動および砂移動を $16 \mathrm{~mm}$ カメラとモータードライブカメラで追跡した洗掘実験な らびに洗掘穴内における流況，流速について詳細な測定 を行ったが, 水平噴流による洗掘過程特性を記すと以下 のようである.ごく初期においては噴出流はほぼ砂面に 沿って直進するが，ほぼ瞬問的に噴出孔直下流に発生す る渦によって洗掘穴の方へ弯曲する. そのため, 深さ方 向の洗掘が卓越し，洗掘穴の下流側斜面の傾斜は漸次増 大していき, 弯曲噴流の上下方向の動摇が顕著になる. 洗掘穴下流側斜面の傾斜がほぼ水中安息角程度になると 弯曲噴流の動摇に対応して洗掘穴下流側斜面の不安定部 分が間欠的に崩落し，斜面ほほぼ一定勾配を保ちながら 洗掘穴下流の砂堆頂を越えて出ていく砂量によって洗掘 が進行していくようになる。このように，水平噴流によ

\author{
斎藤隆* \\ By Takashi SAITOU
}

る洗掘は, その洗掘機構から, 河床変動量が小さく噴出 流がほぼ直進している初期洗掘, 弯曲噴流の再接触流に よって哚さ方向の洗掘が卓越する中期洗掘および洗掘が ほぼ相似な形状を保ちながら進行していく後期洗掘に大 別することができる。

初期洗掘は前述した研究でかなり明らかにされている ので，本文は中期および後期洗掘における現象ならびに その機構の究明を目的とする.そのためには，砂移動に 大きく関与する洗掘砂面近傍の流れの性質，すなわち洗 掘砂面にそう壁面せん断力の場所的変化を明らかにする ことが必要である．中期および後期洗掘における洗掘面 上の流れを単純化すると，床面より最大洗掘深さに比例 した高さの位置から噴出する弯曲噴流が床面に衝突した 後形成される壁面噴流の流れとみなすことができる．こ のようにモデル化すると, 洗掘砂面に沿う流れの特性が 結局最大洗掘深さで与えられるので5),6), 流れの時間的 変化は最大洗掘深さの時間的変化によって表現される.

本文においては, 洗掘の実験結果とその特性を記述し た後, まず非平衡状態の砂移動を取り入れた河床変動の 基礎式を導き，噴流特性をくりこんだ流れのモデルおよ び中・後期洗掘における流れのはく離と洗掘穴下流側斜 面の間欠的崩落のモデルを用い, 洗掘過程の解析を行っ たものである.また，下流水深の小さい場合には洗掘の 途中において, 洗掘深, 形状および水深との関連で周期 的に噴出流の弯曲方向が上向き・下向きに変化する特徵 的な現象がみられるので, この現象の発生条件および最 大洗掘深さなどに与える影響を実験的に調べ，弯曲噴流 の変流条件によって現象の定性的説明を試みた.なお,噴 流特性やせん断力については，壁面噴流 ${ }^{4)}$, 弯曲噴流 ${ }^{5}{ }^{\text {お }}$ よび弯曲噴流が壁面に再接触後形成される壁面噴流 ${ }^{6)}$ に 関する著者の研究の結果を用いる. 本文では便宜上，報 文 I,II,III とよぶことにする。 

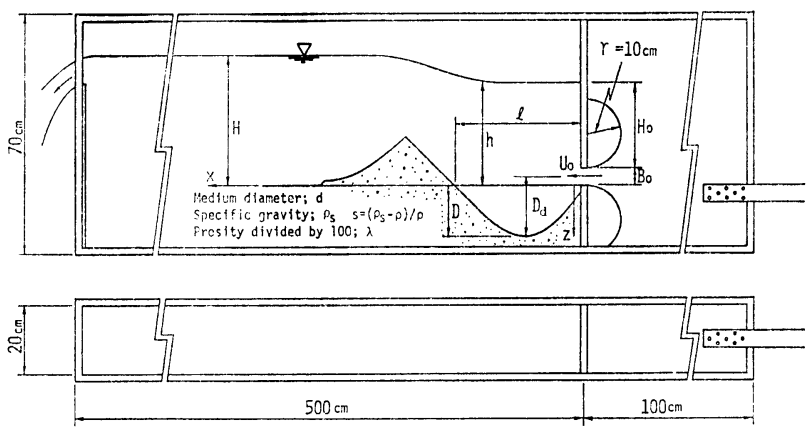

図-1 実験装置および記号説明

\section{2. 実験装置と実験方法}

実験に用いた水槽は 図一1 の両面有機ガラス張りの鉄 枠製のもので，上流端には噴流発生装置を，下流端には 水位調節用の可動堰が設置されている，なお，同図には 本文で用いる記号の説明を記入してある.

実験砂は粒度加積曲線を 図一2 に示したほぼ均一な 8 種類のもので, その特性を図の下方に表示した。ここに $d$ は中央粒径， $W_{0}$ および $U_{* c 0}$ はそれぞれ Rubeyの 式抢上び岩垣の式で計算した沈降速度と限界摩擦速度で ある。

実験は $d / B_{0} \fallingdotseq 0.03,0.05,0.10, u_{0}^{2} /$ $s g d \fallingdotseq 15,60,200$ の各 3 通りを規準に ᄂ, $B_{0}=0.97 \sim 2.60 \mathrm{~cm}, \quad u_{0}=35 \sim 200$ $\mathrm{cm} / \mathrm{s}$ と変えて $d / B_{0}=0.014 \sim 0.435$, $u_{0}{ }^{2} / s g d=13 \sim 230$ の範囲で行った.

洗掘形状および最大洗掘深さの時間的 変化はモータードライブを装着した 35 $\mathrm{mm}$ カメラで水槽の側面より撮影し，実 寸の $1 / 2$ の大きさに投影して読みとっ た. 初期拉よび中期洗掘では $1 / 4$ 秒間隔 で連続撮影し，以後は対数目盛上で同間 隔となる時間間隔で撮影した. 後期洗掘 では洗掘穴下流側斜面の間欠的崩落のた め, 洗掘形状の変化が大きいので, 1 3 秒間隔で撮影した写真 4 6 枚から決め た平均形状を洗掘形状とした.

代表的な実験においては，洗掘穴内に 抢ける流れと砂移動との関連を把握する ために，噴出孔より間欠的に色素を流し て $8 \mathrm{~mm}$ カメラで撮影した.

洗掘がほとんどみられなくなった状態 (実験時閒 30 分〜 4 時間) での洗掘穴 内, および石高で作製した洗掘穴（図一 3 (b) に実線で示した形状) 内における
流速分布を内径 $1.8 \mathrm{~mm}$, 外径 $2.2 \mathrm{~mm}$ のステン レス管で製作したピトー管で詳細に測定した。な お，ピト一管の方向は上流から色素を流して流れ の方向に一致させている.

\section{3. 実験結果とその考察}

\section{(1) 洗 掘形状}

洗掘形状を規定する無次元量は次式のように表
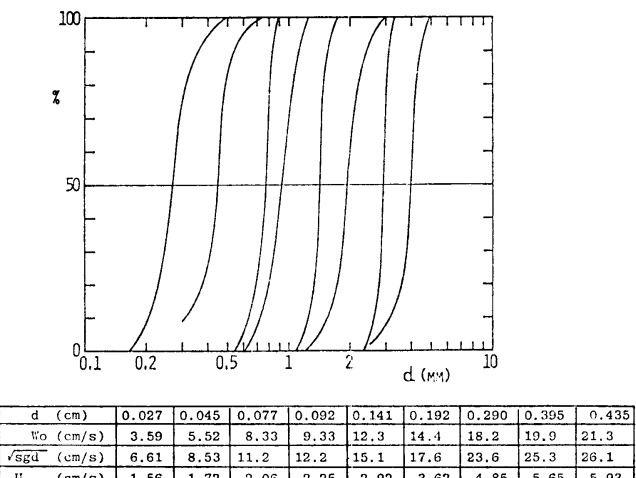
\begin{tabular}{|c|c|c|c|c|c|c|c|c|c|}
\hline$\sqrt{\mathrm{Sg}}(\mathrm{cm} / \mathrm{s})$ & 6.61 & 8.53 & 11.2 & 12.2 & 15.1 & 17.6 & 23.6 & 25.3 & 26.1 \\
\hline$U_{* \mathrm{*O}}(\mathrm{cm} / \mathrm{s})$ & 1.56 & 1.72 & 2.06 & 2.25 & 2.92 & 3.62 & 4.85 & 5.65 & 5.93 \\
\hline
\end{tabular}

\section{図一2 実験砂の粒度加積曲線}

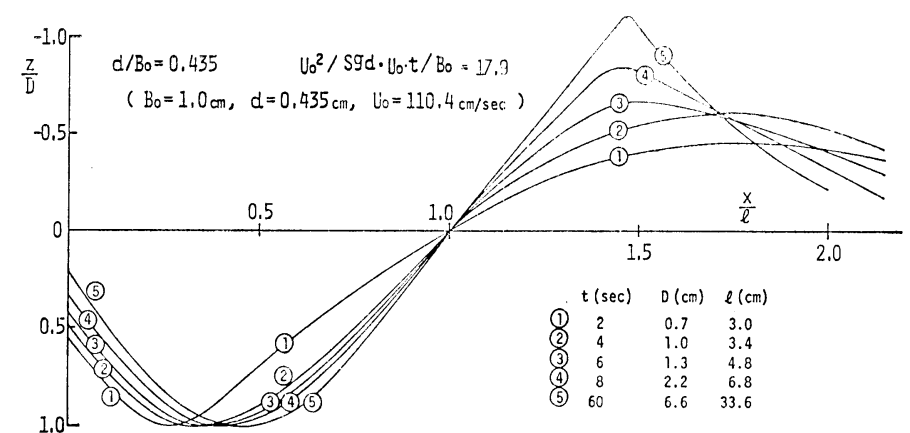

図一3（a）初期および中期洗掘形状

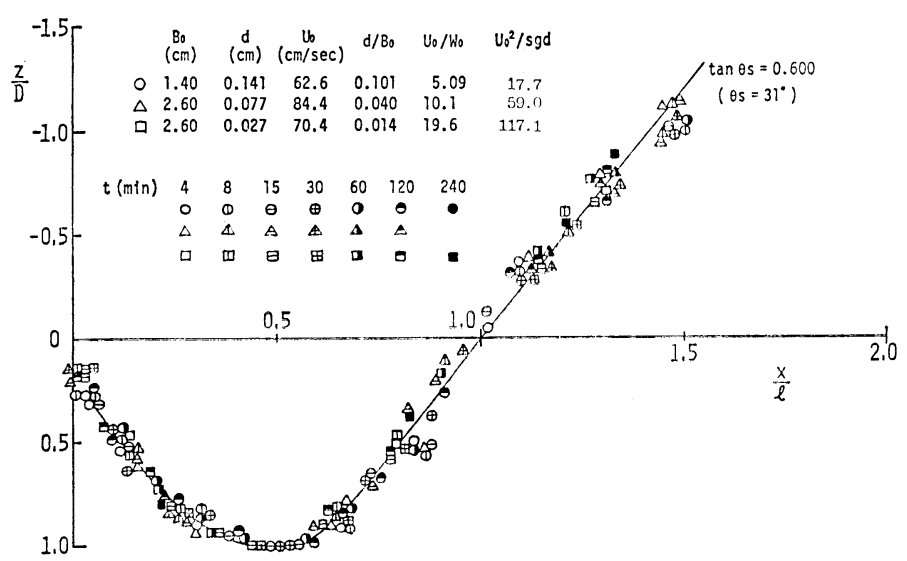

図一3 (b) 後期洗掘形状 
わされよう。

$$
\begin{aligned}
\frac{z}{B_{0}}= & f_{1}\left(\frac{x}{B_{0}}, \frac{u_{0} t}{B_{0}}, \frac{u_{0}{ }^{2}}{s g d}, \frac{\sqrt{s g d} \cdot d}{\nu}, \frac{d}{B_{0}},\right. \\
& \left.\frac{H}{B_{0}}, s\right)
\end{aligned}
$$

下流水媣 $H / B_{0}$ の影響は後に検討することにして, 上 式中の各無次元量について検討していく.

洗掘形状 $z=f(x)$ を最大洗掘深さ $D$ および洗掘穴 の長さ $l$ で無次元化して描いたのが 図一3である. 図一 3(b) の後期洗掘では 洗掘形状はこの無次元表示によっ て統一的に表わすことができ, 洗掘穴下流側斜面の水平 とな寸角度は $d / B_{0}, u_{0}{ }^{2} / s g d$ などに関倸なく約 $31^{\circ}$ であ る. 図一-3(a) に一例を示した初期㧍よび中期洗掘にお ける洗掘形状をみると, 洗掘穴での最大洗掘深断面の相 対的位置加時間的に下流に移動したり， $u_{0}{ }^{2} / s g d$ や $d / B_{0}$ によって複雑に変化するなどのため, 形状を統一的に表 示することは困難である.

洗掘形状の無次元化に用いた $D$ と $l$ との関係を描いた のが 図一4 である. $D / B_{0}<2$ の範囲では $l / B_{0}$ は粗度表 示 $d / B_{0}$ の影響をも受け, $d / B_{0}$ が大きいほど $l / B_{0}$ は大

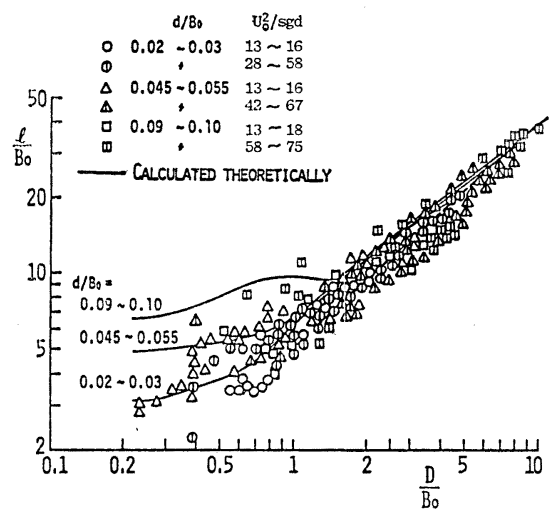

図-4 最大洗掘深さ $D / B_{0}$ と洗掘長 $l / B_{0}$ の関係

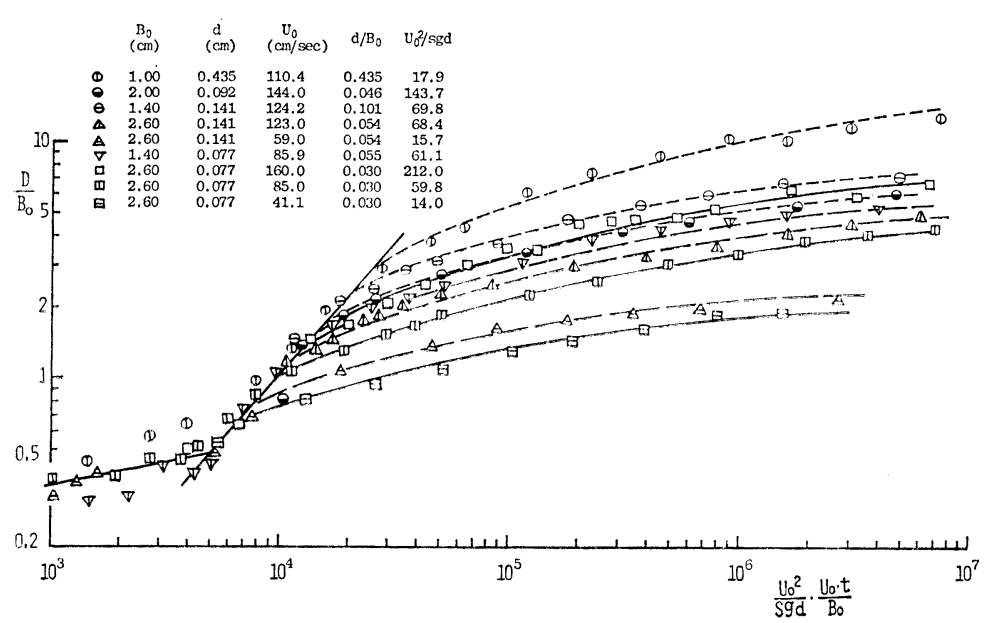

図-5 最大洗掘深さの時間的变化
きい值をとる. $D / B_{0}>2$ になると，実験条件に無関係 に $l / B_{0}$ は $D / B_{0}$ とほぼ比例関係にある.したがって, 後期洗掘における洗掘形状は一つの基準長で統一的に表 示される，なお，図中の曲線は後述する洗掘計算の結果 である.

\section{（2）最大洗掘深さの時間的変化}

前述したように, 後期洗掘における洗掘形状は相似的 な形状として無次元表示できることがわかったので，洗 掘深さの時間的変化を考察するにあたっては最大洗掘哚 さについて検討する. 砂粒の水中比重 $s$ の変化は小さ く，また，実験で $\sqrt{s g d} \cdot d / \nu$ は洗掘にほとんど影響しな いので，これらを無視し，下流水深が十分深い $\left(H / B_{0}\right.$ $\rightarrow \infty)$ 場合には式 (1) は次のように書きかえることがで きる

$$
\frac{D}{B_{0}}=f_{2}\left(\frac{u_{0}^{2}}{s g d}, \frac{d}{B_{0}}, \frac{u_{0} t}{B_{0}}\right)
$$

後述する河床変動の式によると, 洗掘の進行は無次元 時間 $\tau=\left(u_{0}{ }^{2} / s g d\right)^{m-1 / 2} \cdot u_{0} t / B_{0}$ で規定される. 洗掘は掃 流によるものとみられるので，指数型流砂公式の指数 $m=3 / 2$ とおいて, 最大洗掘樑さの時間的変化を示した ものが 図一5 である. $\tau \fallingdotseq 0.5 \times 10^{3}, D / B_{0} \doteqdot 0.5$ ，ならび に $\tau \fallingdotseq 0.7 \sim 2 \times 10^{4}, D / B_{0} \fallingdotseq 1 \sim 2$ で実験描点の傾向が異 なり，それぞれが初期ならびに中期洗掘の限界である。

\section{（3）洗掘穴内における流況}

石膏面にほぼ均一な砂をペイントで張付けた後期洗掘 穴 (図-3 (b) の実線) 内で測定した流速分布から作成 した等流速線図の一例が 図一6 である. 図中の $x_{R}, x_{s}$, $x_{d}$ は，報文 II， III で報告した弯曲噴流および弯曲噴流 による壁面噴流の特性に関する結果を用い，段落高さが 最大洗掘梁さであるとして計算した再接触位置，加速流 域および定速流域の境界位置であ る. 再接触後洗掘砂面にそ。て境 界層が発達していくが，境界層外 縁流速の変化の状態から, 図一10 に概況を示してある弯曲噴流によ る壁面噴流と同様に，加速流域， 定速流域打よび減速流域に分ける ことができる．図のように各領域 の境界位置を対応させると洗掘砂 面にそう流れの各領域は最大洗掘 深さの段落境界面にそって形成さ れる弯曲噴流による壁面噴流の各 領域の範囲にほぼ一致している.

境界層外縁流速があまり変化し ない定速流域における最大流速 


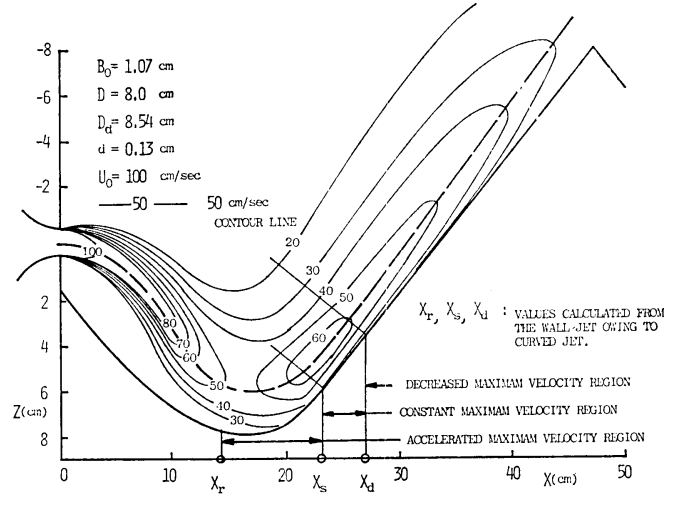

図一6 洗掘穴内の等流速線図

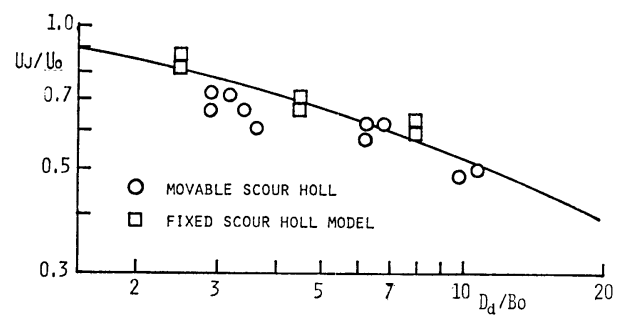

\section{図一7定流速域における境界層外縁流速 $\boldsymbol{u}_{j} / \boldsymbol{u}_{0}$ と $D / B$ との関係}

$U_{j}$ と噴出流速 $U_{o}$ の比を噴出孔中心から測った段落高 さ $D_{d} / B_{0}\left(D_{d}=D+0.5 B_{0}\right)$ に対して図示したものが 図 -7 である. 描点口は石膏製砂張りの洗掘穴で，描点○ は終極状態に近いときの洗掘穴内で測定したものであ る.また, 図中の曲線は次式で与えられる段落固定床(報 文 III) による結果である.

$$
\frac{u_{j}}{u_{0}}=\sqrt{3.5 /\left(\frac{D_{d}}{B_{0}}+3.0\right)}, \quad \frac{D_{d}}{B_{0}}=\frac{D}{B_{0}}+\frac{1}{2}
$$

\section{4. 河床変動の基礎式}

非平衡状態の砂移動の考え方を河床変動の基礎式に導 入することはほぼ同時に著者 ${ }^{7)}$ ら土屋 ${ }^{3)}$ とによってそ れぞれ独立に sand wave の発生限界の問題, 洗掘の問 題に対して適用された. 雨者と同様に, Einstein の砂移 動モデルに基づいて誘導した非平衡状態での流砂関数の 概要を述べ，河床変動について考察する.

砂粒の移動確率 $P$ および平均移動距離 $L$ は砂粒の性 質および流れの場によって規定される. したがって，平 衡状態および非平衡状態における流砂量をそれぞれ $q_{B 0}$, $q_{B}$ とすると, 河床表面の単位面積から単位時間に運動 状態に入る砂量は $q_{B_{0}} / L$, 移動から停止にかわる砂量は $q_{B} / L$ であるから, 無次元表示 $\Phi_{0}=q_{B 0} / \sqrt{s g d^{3}}, \Phi=q_{B} /$ $\sqrt{s g d^{3}}$ を導入して, 砂粒の連続条件は次式で与えられ
る・

$$
\frac{\partial \Phi}{\partial \xi}=\frac{B_{0}}{L}\left(\Phi_{0}-\Phi\right), \quad \xi=\frac{x}{B_{0}}
$$

上式を $\xi=0$ で $\Phi=\Phi_{1}=\left(q_{B} / \sqrt{s g d^{3}}\right)_{\xi=0}$ なる条件で積 分すると次式となる。

$$
\Phi-\Phi_{1}=\exp \left(-\int \frac{B_{0}}{L} d \xi\right) \int_{0}^{\xi} \frac{B_{0}}{L} \Phi_{0} \exp \left(\int \frac{B_{0}}{L} d \xi\right) d \xi
$$

Einstein ${ }^{8}$ は平衡状態の流砂関数の式を導いているが, 式形が複雑であるので，ここでは河床勾配 $\theta$ による修 正 ${ }^{9)}$ 施した次式を用いる.

$$
\Phi_{0}=K\left(\frac{u_{*}{ }^{2}}{s g d} \frac{1}{\sin \theta+\mu \cos \theta}\right)^{m}\left(1-\frac{u_{* c 0}{ }^{2}}{u_{*}{ }^{2}}\right)
$$

ここに, $\mu$ は砂粒間の摩擦係数, $\mu_{*}$ は摩擦速度であ る.なお, 式 (4)，(5) のLについて, Einstein は次 式を与えている.

$$
L=\lambda_{1} d /(1-P)=\lambda_{1} d\left(1+\Phi_{0} / A_{*}\right)
$$

ここに， $\lambda_{1}$ および $A_{*}$ は実験によって決められる常 数で, Einstein によると $\lambda_{1}=100, A_{*}=1 / 43.5$ である. 河床変動の基礎式

$$
\frac{\partial z}{\partial t}=\frac{1}{1-\lambda} \frac{\partial q_{B}}{\partial x}
$$

に式 (4)〜 (6) を代入して無次元化すると次式となる.

$$
\begin{aligned}
\frac{\partial \zeta}{\partial \tau}= & \frac{K}{1-\lambda} \frac{d}{L}\left\{\Phi_{0 *}-\Phi_{1 *}-\exp \left(-\int \frac{B_{0}}{L} d \xi\right)\right. \\
& \left.\int_{0}^{\xi} \frac{B_{0}}{L} \Phi_{0 *} \exp \left(\int \frac{B_{0}}{L} d \xi\right) d \xi\right\} \cdots \cdots \cdots . . .
\end{aligned}
$$

ここに， $u_{m}$ は断面内最大流速（境界層外縁流速）

$$
\begin{aligned}
\tau= & \left(\frac{u_{0}^{2}}{s g d}\right)^{m-1 / 2} \frac{u_{0} t}{B_{0}}, \quad \zeta=\frac{z}{B_{0}} \\
\Phi_{0 *}= & \left\{\left(\frac{u_{*}}{u_{m}}\right)^{2}\left(\frac{u_{m}}{u_{0}}\right)^{2} \frac{1}{\sin \theta+\mu \cos \theta}\right\}^{m} \\
& \left\{1-\frac{u_{* c 0}{ }^{2}}{s g d}\left(\frac{u_{m}}{u_{*}}\right)^{2}\left(\frac{u_{0}}{u_{m}}\right)^{2}\left(\frac{s g d}{u_{0}}\right)^{2}\right\} \\
\Phi_{1 *}= & \left(\Phi_{0 *}\right)_{\xi=0}
\end{aligned}
$$

着色砂の実験 ${ }^{10)}$ によると, $L$ の式における分母（1$P$ ) は $P$ の影響を過大に評価しており，むしろ $L=\lambda_{1} d$ の方が適当とされているので, 簡単に $L=\lambda_{1} d$ とおく と, 上流からの移動砂量がない場合 $\left(\Phi_{1}=0\right)$ には上式 は次式となる.

$$
\begin{aligned}
& \frac{\partial \zeta}{\partial \tau}=\frac{K}{\lambda_{1}(1-\lambda)}\left\{\mathscr{D}_{0 *}-\frac{\lambda_{1} d}{B_{0}} \exp (-\xi)\right. \\
& \left.\int_{0}^{\xi} \Phi_{0 *} \exp (\xi) d \xi\right\}
\end{aligned}
$$

なお, 式 (7) の $L$ を用いると, 式 (9) は次式となる.

$$
\begin{gathered}
\frac{\partial \zeta}{\partial \tau}=\frac{K}{\lambda_{1}(1-\lambda)}\left\{\Phi_{0 *}-\frac{\lambda_{1} d}{B_{0}} \exp \left(-\int \frac{d \xi}{1+\Phi_{0} / A_{*}}\right)\right. \\
\left.\int_{0}^{\xi} \frac{\Phi_{0 *}}{1+\Phi_{0} / A_{*}} \cdot \exp \left(\int \frac{d \xi}{1+\Phi_{0} / A_{*}}\right) d \xi\right\}
\end{gathered}
$$


(12)

以上のことから, 洗掘砂面にそう $u_{*} / u_{m}$ および $u_{m} / u_{0}$ の分布がわかれば, 式 (11) の $\Phi_{0 *}$ が $\xi$ の関数として 計算され，式 (9) あるいは式 (11) によって各瞬間にお ける河床変動速度 $\partial \zeta / \partial \tau$ が求められ，洗掘の進行を時間 的に追跡していくことができる．したがって，洗掘の解 析には洗掘面上における $u_{*} / u_{m}$ および $u_{m} / u_{0}$ の分布を 適切に表示することが必要で，そのために前述の実験結 果と壁面噴流に関する知見に基づて次のように流れを モデル化する.

\section{5. 流れおよび砂移動のモデル化}

洗掘穴内における流れおよび砂移動を各期ごとにモデ ル化し, それによる洗掘の解析方法について考察する.

\section{（1）初期洗掘}

河床変動量がごく小さく噴出流はほぼ砂面に沿って直 進しているので, この時期における流れは粗壁面に沿っ て噴出した壁面噴流とみなせる.

壁面噴流は最大流速が一定である流れの形成領域と最 大流速が $\sqrt{x}$ に逆比例して減少していく流れの確立領域 とに分けられる．報文（I）により，噴出孔より両領域 の境界までの距離 $x_{E}$ は噴出孔上端からの速度不連続面 の拡散と噴出孔下端からの境界層の発達とによって決ま り, Manning-Strickler の抵抗則を用いて次式のように 与えられる（報文 (I) の式 (10)).

$$
\frac{x_{E}}{B_{0}} /\left\{1-0.248 \frac{x_{E}}{B_{0}}\left(\frac{d}{B_{0}}\right)^{1 / 4}\right\}=14.44 \cdots \cdots
$$

$x \leq x_{E}$ における摩擦速度は次式のとおりである.

$$
\left(\frac{u_{*}}{u_{m}}\right)^{2}=0.00785\left(\frac{d}{x}\right)^{5 / 12}
$$

次に, $x \geq x_{E}$ における最大流速の低減は次式で与え られる。

$$
\frac{u_{m}}{u_{0}}=\left(\frac{x_{E}+x_{0}}{x+x_{0}}\right)^{1 / 2}, \frac{x_{0}}{B_{0}}=4.43
$$

さらに, 主流部流れの乱れを考虑した境界層速度分布 則で計算した流れの確立領域における局所抵抗係数（報 文（I） 5 章図一17）を計算の簡略化のために実験式化 すると次式となる.

$$
\begin{aligned}
\left(\frac{u_{*}}{u_{m}}\right)^{2}= & \frac{1}{2}\left\{0.0128+0.103\left(\frac{d}{B_{0}}\right)^{1 / 2}\right\} \\
& \left(\frac{x}{B_{0}}\right)^{-\left\{0.237+0.15 \cdot \exp \left(-100 d / B_{0}\right)\right\}}
\end{aligned}
$$

$x \leq x_{E}$ では式 (15) の代りに $u_{m} / u_{0}=1$ と式 (14) と を， $x \geq x_{E}$ では式 (15) の $x_{E}$ に式 (13) を代入したも のと式 (16) とを式 (11) の右辺に代入して積分すると各 断面における河床の変動速度が得られる. 初期洗掘にお

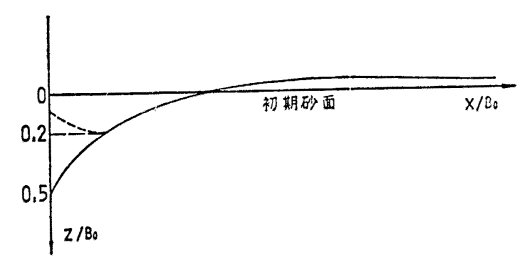

\section{図一8 初期流掘計算の説明図}

いては $u_{*} / u_{m}$ および $u_{m} / u_{0}$ は時間と無関係に与えられ ているので, 洗掘穴の長さ $l$ は一定であり, 河床変動量 は時間に比例して増大していく。この計算による初期洗 掘形状は図一8 に実線で示すように $x=0$ において最大 の洗掘深さを与えるが, 実際には瞬間的に噴出孔直下流 に発生する Roller によって $x=0$ 付近は埋めもどされ て図の点線のような形状である.このように, Roller が 噴出孔近くの砂移動に大きく影響しているが， $8 \mathrm{~mm}$ 力 メラで撮影したものを参考にして，噴出孔断面 $(x=0)$ における洗掘深さの計算值が $\left(z / B_{0}\right)_{\mathrm{cal}}=0.5$ となる洗 掘形状を計算し, 逆流による埋めもどしを考慮して図一 8 の破線のように $x=0$ 付近での 洗掘深さは一定值 $z /$ $B_{0}=0.2$ とし, それより下流の洗掘形状は計算した形状 とする. 以後, 次に述べる中期洗掘にお污る流れを用い て河床変動を計算していく.この場合, 中期洗掘と異な るのは洗掘穴下流斜面での流れのはく離がないことであ る.

\section{（2）中期および後期洗掘}

すでに 2. (3) で述べたように，中期および後期洗掘に おける洗掘面にそう流れは図一9に概略を示すように, 弯曲噴流が最大洗掘深さの位置にある段落境界面に再接 触して, その下流に形成される壁面噴流の流れで近似す ることができる.

弯曲噴流による壁面噴流流れの 概要は 図一10 のとお りで, 報文 (II), (III) より各領域の境界位置や境界層外 縁流速などの洗掘に必要な諸量について簡単に説明す る.

\section{a) 再接触位置 $x_{R}$}

弯曲噴流が境界面に再接触する $x$ 座標 $x_{R}$ は噴出流 の拡散, 曲率および段落高さに規定されるが, 終局的に は $x_{R} / D$ は $D / B_{0}$ のみで表示され, 両者の関係 $x_{R} / D=$

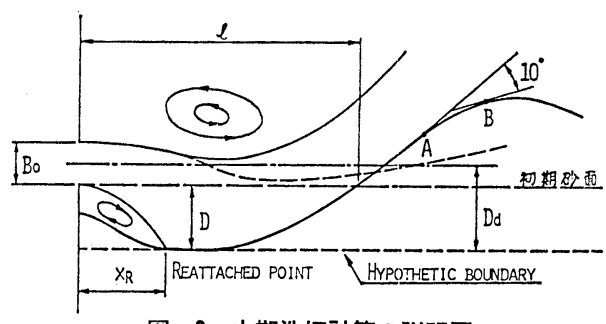

図一9 中期洗掘計算の説明図 


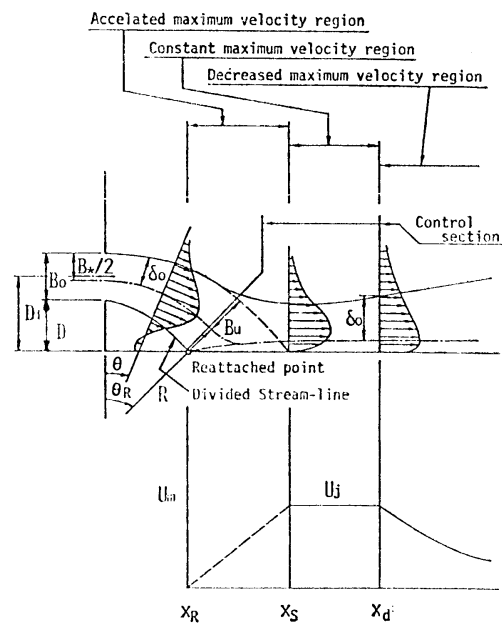

図一10 弯曲噴流による壁面噴流の流況と境界層外縁 流速の変化

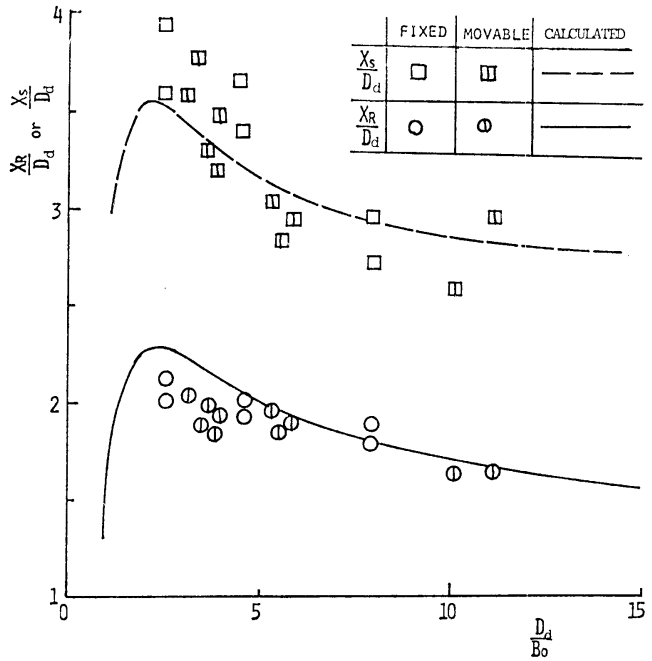

図一11 再接位置 $\boldsymbol{x}_{R} / \boldsymbol{D}$, 加速流域と定速流域の境界 位置 $\boldsymbol{x}_{\boldsymbol{s}} / \boldsymbol{D}$ と $\boldsymbol{D} / \boldsymbol{B}_{0}$ の関係

$f\left(D / B_{0}\right)$ は 図一11（報文 III, Fig. 13）に示すとおりで ある.

b） 加速流域 $x_{R} \leq x \leq x_{s}$

再接触後, 壁面近傍における流れが加速されるのは壁 面に垂直方向の速度成分による流れの縮流する結果によ るものであることより，再接触点における $1 / 10$ 最大流 速点より再接触角 $\theta_{R}$ で延長した直線が境界面と交差す る位置を 加速域の境界位置として求めた結果が 図一11 の破線である.図中の描点は洗掘実験および固定洗掘穴 内で測定した流速分布から求めたものである.

加速流域における境界層外縁流速の変化は $x=x_{R}$ で $u_{m} / u_{0}=0, x=x_{s}$ で $u_{m} / u_{0}$ が式 (3) に帰着することか ら簡単に次式の直線分布を仮定する（報文 III 境界層の 発達).

$$
\frac{u_{m}}{u_{0}}=\sqrt{3.5 /\left(\frac{D}{B_{0}}+3.5\right)} \frac{x-x_{R}}{x_{s}-x_{R}}
$$

c） 定速流域 $x_{s} \leq x \leq x_{d}$

定速流域と減速流域との境界位置は後述の減速流域の 最大流速の逓減式 (19)の $u_{m} / u_{0}$ が定速流域における式 (3) の $u_{j} / u_{0}$ と一致する位置として次式で与えられる.

$$
\frac{x_{d}}{B_{0}}=4.4\left(K_{u 1} \cdot K_{u 2}\right)^{2}\left(\frac{D}{B_{0}}+3.5\right)-5.9
$$

d) 減速流域 $x_{d} \leq x$

滑面水平壁面噴流における最大流速の逢減式

$$
\left(\frac{u_{m}}{u_{0}}\right)_{H \cdot S}=\sqrt{15.4 /\left(\frac{x}{B_{0}}+5.9\right)}
$$

を基準とし, 粗・滑段落境界面で行った測定結果から， 段落高さ $D / B_{0}$, 粗度表示 $d / B_{0}$ の影響を表わす係数 $K_{u 1}, K_{u 2}$ を導入した結果が次式である（報文 III, 式 (21), (22)).

$$
\begin{aligned}
\frac{u_{m}}{u_{0}}= & K_{u_{1}} \cdot K_{u 2} \sqrt{15.4 /\left(\frac{x}{B_{0}}+5.9\right)} \\
K_{u_{1}}= & \left\{2.4 /\left(\frac{D}{B_{0}}+1.9\right\}^{1 / 8}\right. \\
K_{u_{2}}= & \left\{0.176 \log _{10}\left(\frac{D}{B_{0}}\right)\right. \\
& +0.553\}\left(\frac{d}{B_{0}}\right)^{2} / 4\left\{\left(\frac{d}{B_{0}}\right)^{2}+0.005\right\}
\end{aligned}
$$

以上の実験式で与えられる定速流域, 減速流域におけ

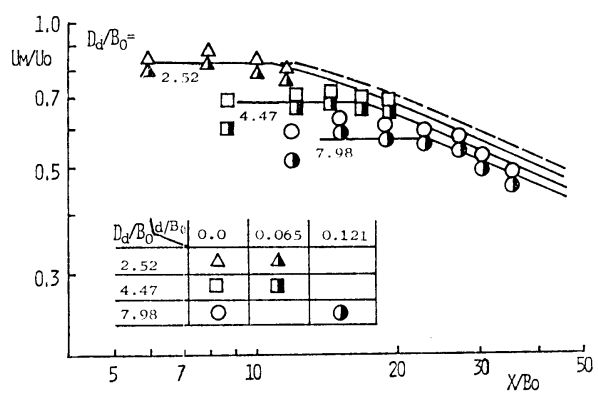

図一12 弯曲噴流による壁面噴流および洗掘砂面にお ける境界層外縁流速の変化

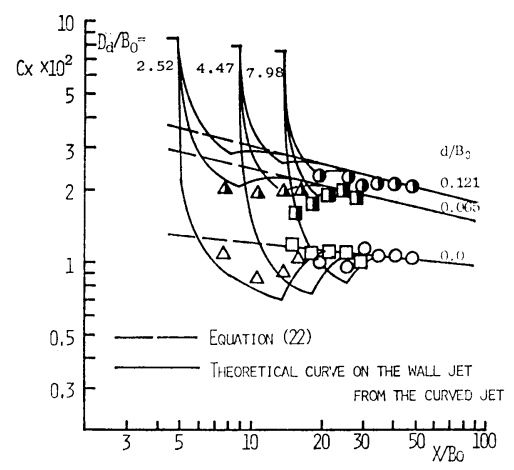

図一13 弯曲哄流による壁面唭流および洗掘砂面上の 局所抵抗係数 
る最大流速の変化と固定洗掘穴内で測定した結果を比較 したものが 図一12 である.

図一13 は再接触噴流による壁面噴流の 局所抵抗係数 で，実曲線は報文（III）の方法で解析した結果である. 計算の簡略化のために再接触点より下流の局所抵抗係数 の分布を図中の破線で与えると, 摩擦速度の分布は次式 となる。

$$
\begin{aligned}
\left(\frac{u_{*}}{u_{m}}\right)^{2}= & \frac{1}{2}\left\{0.0145+0.103\left(\frac{d}{B_{0}}\right)^{1 / 2}\right\} \\
& \left(\frac{x}{B_{0}}\right)^{-\left\{0.237+0.15 \cdot \exp \left(-100 d / B_{0}\right)\right\}}
\end{aligned}
$$

\section{（3）中期および後期洗掘における洗掘計算法}

洗据砂面にそう $u_{m} / u_{0}$ が式 (3), (20) で, $u_{*} / u_{m}$ が 式 (22) で与えられたので, 式 (10) で計算した $\Phi_{0 *}$ を 式 (11) に代入して積分すると, 各瞬間における河床変 動速度の場所的分布が求められ，洗掘を時間的に追跡す ることができるのであるが，前述したように，中期洗掘 では洗掘穴下流側斜面で流れがはく離しており, 後期洗 掘では洗掘穴下流側斜面が間久的に崩落しているので, これらを河床変動の計算に次のように導入する.

中期洗掘: 拡大流れに扔いて拡大角が $7^{\circ} \sim 10^{\circ}$ で流れ がはく離することが知られている，また，はく離の下流 で砂粒が巻きあげられているので, 時刻てにおける洗掘 砂面の最大傾斜点（図一9のA点, $x=x_{A}$ ) からその傾 斜角より $10^{\circ}$ 緩い点（図一 9 の $\mathrm{B}$ 点, $x=x_{B}$ ) までの間 に扔ける $\Phi_{0} / L(x$ 地点から動き出す砂量) を次のよう におく.

$$
\left.\begin{array}{lc}
\frac{\Phi_{0}}{L}=\left(\frac{\Phi_{0}}{L}\right)_{x=x_{A}} \frac{x_{B}-x}{x_{B}-x_{A}} \text { for } x_{A} \leq x \leq x_{B} \\
\Phi_{0} / L=0 & \text { for } x \leq x_{B}
\end{array}\right\}
$$

$x_{R} \leq x \leq x_{A}$ では前節のモデル流れで与えられる $\Phi_{0}$ を, $x \geq x_{A}$ では上式の $\Phi_{0}$ を式 (12) の右辺に代入して 積分すると, 河床変動速度 $\partial \zeta / \partial \tau$ の場所的変化が得ら れ, 次の $\Delta \tau$ 時間の河床変動量が求められる.この場合, $\xi_{B}=x_{B} / B_{0}$ より下流の堆積速度は,

$$
\frac{\partial \zeta}{\partial \tau}=-\frac{K}{1-\lambda} \frac{d}{B_{0}} \exp (-\xi) \int_{0}^{\xi_{B}} \Phi_{0 *} \exp (\xi) d \xi
$$$$
\text { for } \xi \geq \xi_{B}
$$

となり， $\xi_{B}$ より下流の堆積量は指数関数で減少してい <.

後期洗掘: 中期洗掘が進行して洗掘穴下流側斜面にほ ぼ水中安息角程度の勾配部分が現われると, この部分で 流れがはく離し掃流されてきた砂がその下流砂面に堆積 して不安定な斜面を形成するようになる.この不安定部 分が噴出流の動摇によって間欠的に洗掘穴に崩落し, 洗 掘穴下流側斜面は平均的にほぼ水中安息角程度の勾配を

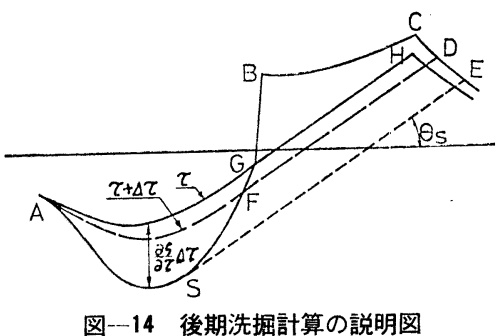

なして洗掘が進行する.この崩落現象を次のようにして 河床変動一導人した. 寸なわち，

(i) 前節で説明した流れのモデルで時刻てにおける 洗掘砂面（図一14の A GH 曲線）.上の $u_{m} / u_{0}, u_{*} / u_{0}$ を 求める.

（ii）（i）の結果を式（12）に代入し，再接触点（図一 14 の A 点, A点より上流側の河床変動は無視する）よ り積分して河床変動速度 $\partial \zeta / \partial \tau$ を $\partial \zeta / \partial \tau=0$ となる断面 （図一14の G 点）まで計算していく.

(iii）図-14の $\mathrm{G}$ 点で流れがはく離するとして， $\mathrm{G}$ 点より下流 $\left(\xi \geq \xi_{G}=x_{G} / B_{0}\right)$ では $\Phi_{0} / L=0$ とおき, 式 (12) の右辺の積分上限 $\xi_{B}$ を $\xi_{G}$ と書きかえて堆積量を 計算する.

(iv) (i)〜 (iii) の計算による $\Delta \tau$ 時間後の形状は図 -14の ASBCDE 曲線となり, 斜面傾斜角が水中安息 角より急になる $\mathrm{S}$ 点より下流の斜面は不安定な斜面であ る.

（v） 斜面傾斜角が水中安息角 $\theta_{S}$ である $\mathrm{S}$ 点から接 線 SE を描き, 容積 $\mathrm{SBCE}$ を求める.

(vi) AS 間では洗掘深さ $\partial \zeta / \partial \tau \cdot \Delta \tau$ に比例して埋め もどされ， $\mathrm{S}$ 断面より下流では $\theta_{S}$ なる一定勾配の斜面 である AFD 曲面を仮定し, 容積 ASEDF を求める.

（vii） 容積 $\mathrm{SGBCE}=$ 容積 ASEDF（容積 $\mathrm{ASF}=$ 容 積 $\mathrm{FBCD}$ ) となる曲線 AFD を試算で求める.

以上の計算で得られた曲線 $\mathrm{AFD}$ が時刻 $\tau+\Delta \tau$ にお ける洗掘形状である。

\section{6. 数值的検討}

最大洗掘媣さの時間的変化, 最大洗掘深さと洗掘長の 関係および洗掘形状を上述の解析モデルで数值的に検討 する.

式中の砂の特性值としては全実験砂の平均值である水 中比重 $s=1.65$, 空幥率 $\lambda=0.4$, 水中安息角 $\theta_{S}=31^{\circ}$ を 用い, 砂粒間の摩擦係数を $\mu=1.0^{13)}$ とする. 洗掘穴内 の砂の移動は掃流形式であるから $m=1.5$ とおき, 移 動砂量強度を規定する係数 $K=4 \sim 20^{11)}$ と, 砂粒の平均 移動距離を与える $\lambda_{1}=80 \sim 300^{12)}$ と検討の 余地がある が, 著者らが, Sand wave の発生限界の検討で用いた 
$\lambda_{1}=100$ と，境界層流れが主流部の影響を受けているこ とを考慮して $K=30$ とおくことにする．以上の諸数值 を用い，式（11）で洗掘を追跡した結果は次のとおりで ある。

$D / B_{0} \sim l / B_{0}$ （図一4）: 初期・中期洗掘では実験 值・計算值とも $d / B_{0}$ が大きいほど $l / B_{0}$ が大き くなっているが, 後期洗掘では両者の值はともに $d / B_{0}$ に関係なく, ほぼ一直線となっている。こ れは, 初期・中期における洗掘形状が移動砂量の 相対的な場所的分布によって決まるのに対し，後 期洗掘においては洗掘穴下流側斜面が一定勾配に 保たれるためである．なお， $u_{0}{ }^{2} / s g d$ が関係しな いのもこのためである.

後期洗掘形状(図一15)：噴出孔直下流の洗掘砂 面上に形成される Roller の逆流による洗掘を考 虑していないため, 噴出孔より最大洗掘深断面ま での計算による洗掘媣さは実験 值よりかなり小さいが，計算に よる洗掘穴下流側斜面の形状は 実験結果とよく一致していて, 噴出流の動摇に伴う斜面の間欠 的崩落が洗掘形状に大きく関与 していることが明らかである.

最大洗掘哚さの時間的変化 （図一16): 最大洗掘深さ $D / B_{0}$ は $d / B_{0}, u_{0}{ }^{2} / s g d$ を parameter として無次元時間 $\tau=u_{0}{ }^{2} / s g d$. $u_{0} t / B_{0}$ で規定され, 計算值と実 験值とはよく一致している. $u_{0}{ }^{2} / s g d$ が大きいほど $D / B_{0}$ が 大きいことは， $u_{0}{ }^{2} / s g d$ が大き いほど移動砂量が大きいことか ら予測されるとおりであるが， $d / B_{0}$ が大きいほど $D / B_{0}$ が大 きくなることは, $u_{m} / u_{0}$ の減少 よりも $u_{*} / u_{m}$ の増加が大き くて, 結果的に $u_{*}{ }^{2} / s g d=u_{0}{ }^{2} /$ $s g d \cdot\left(u_{*} / u_{m}\right)^{2}\left(u_{m} / u_{0}\right)^{2}$ が大き くなるからである.すなわち河 床砂が大きくなると最大流速は 小さくなるが, それ以上に壁面 せん断力が大きくなって, 無次 元掃流力が大きくなるからであ る.

以上のように計算結果は実験 結果とかなり量的にもよく一致 していて, 中期・後期洗掘に抒
ける噴出流の洗掘穴方への弯曲が洗掘の進行に重要な役 割をもっていることが明らかである。

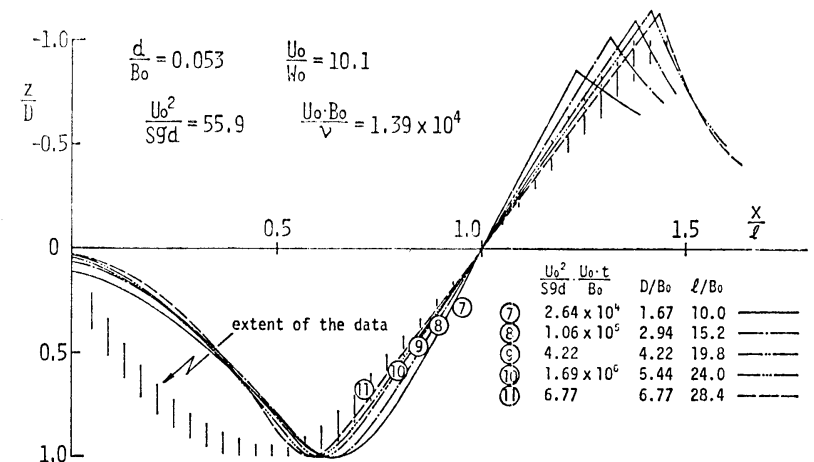

図一15 後期洗掘形状に関する計算結果と実験結果との比較

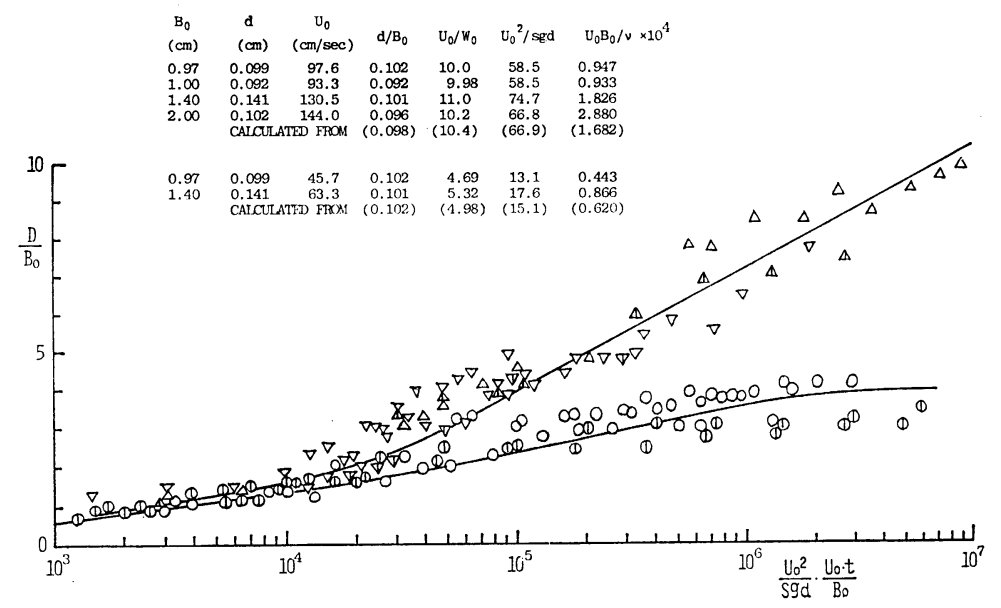

(a) $d / B_{0} \doteqdot 0.1$

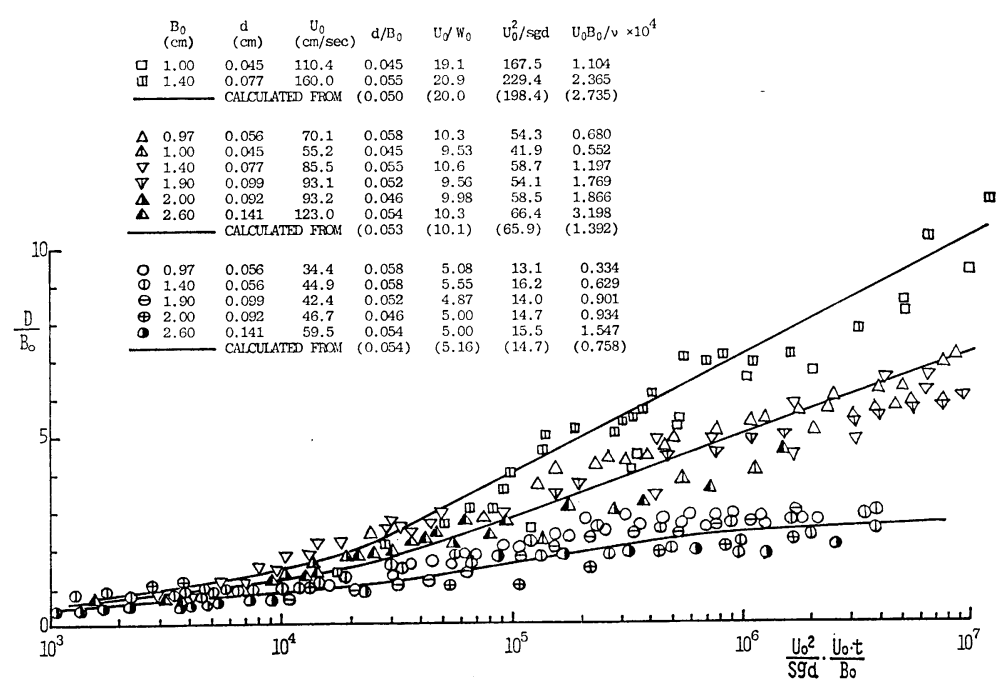

(b) $d / B_{0} \doteqdot 0.05$ 


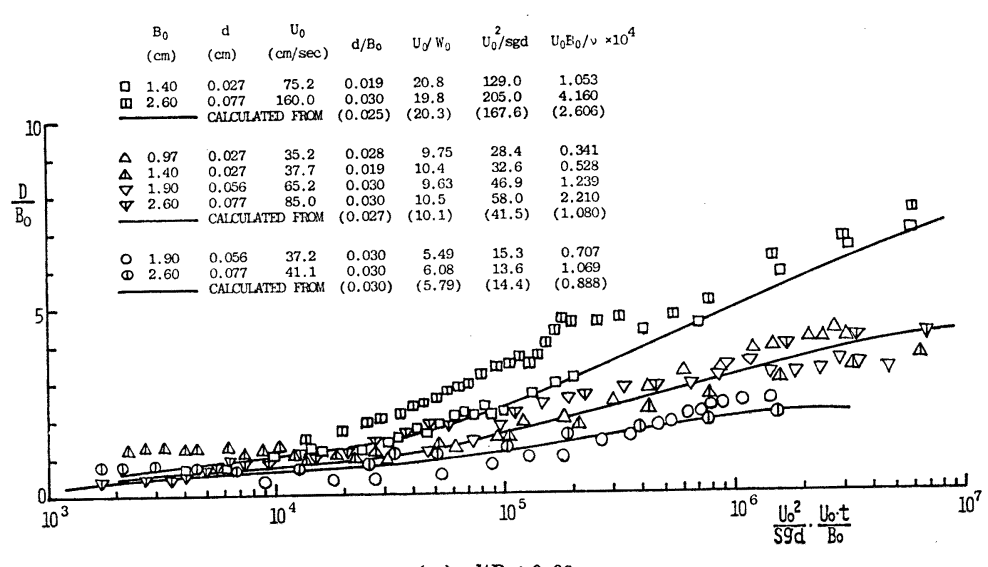

(c) $d / B_{0} \doteqdot 0.03$

図一16 最大洗掘深さの時間的变化

ると, $l_{e} / B_{0} \sim D_{e} / B_{0}$, 洗据形状 における $z / D_{e} \sim x / l_{e}$ との間に

は図一3,4 の関係がある.

\section{（2）間欠的洗掘の発生限界}

初めて下向きの噴出流による 洗掘状態から噴出流が上向きの 流れに変わり洗掘穴が埋めもど されていく直前の最大洗掘哚さ $D_{\boldsymbol{e}}$ (上向き矢印付描点)，およ び次に再び噴出流が下向きに変 わり急激な洗掘が始まる直前の 最大洗掘深さ $D_{\boldsymbol{u}}$ （下向き矢印 付描点）と下流水深との関係を 描いたのが図一18 である．最大洗掘深さの時間的変化 は次のとおりである.すなわち，実験開始より最大洗掘 深さは 図一18の $\mathrm{A}$ 点から $\mathrm{B}$ 点まで増加していき，最大 洗掘深さが $\mathrm{B}$ 点に達すると噴出流が下向きから上向きの 流れに変わり洗掘面上に形成される Roller の逆流で埋 めもどされていく．埋めもどしによって最大洗掘樑さが $\mathrm{C}$ 点になると噴出流が再び下向きの流れに変わって急激 な深さ方向に卓越した洗掘が行われる. 以後, DEF と 噴出流の弯曲方向の変化に対応して最大洗掘深さが変わ っていく．図中の斜線部分は段落境界に再接触する弯曲 噴流の 変流限界に関する 実験描点の範囲で曲線は 報文 （II）の計算值である. 図一16 の洗掘形状から予測され るように上向き流れ (Separated flow) から下向き流れ (Reattached flow)へ変わるときの $H / B_{0}$ と $D_{u} / B_{0}$ の関 倸は段落境界面と洗掘面とであまり違わず, 間欠的洗掘 の絽返しによってその関係は固定床の結果に漸近してい く. 一方, 噴出流が下向きから上向きの流れに変わると きの $H / B_{0}$ と $D_{u} / B_{0}$ との関係は固定床と移動床によっ て大きく異なる.これは洗掘穴下流側斜面に沿って噴き 上る流れによって水表面側にもはく離領域ができ，この 内の渦による圧力（水面低下）によるも のである.

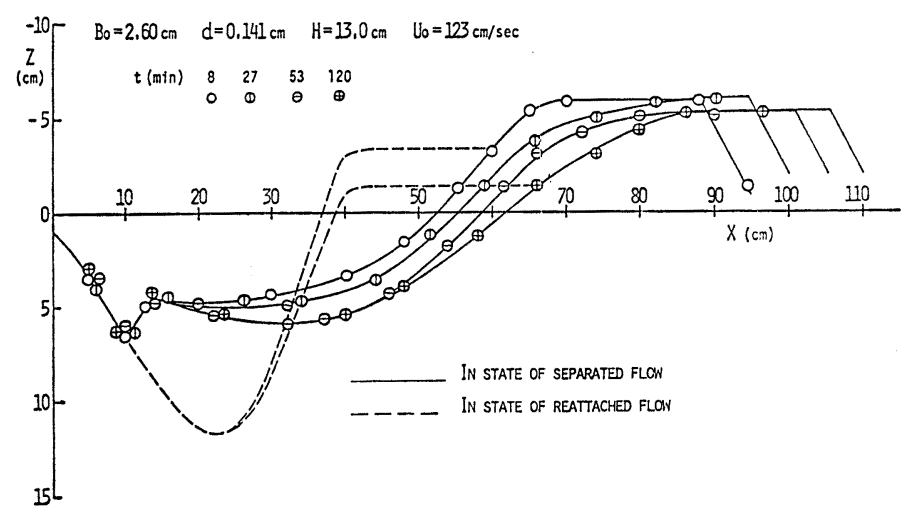

図一17間欠的洗掘における洗掘形状

\section{（3）最大洗掘深さの時間的変化}

下流水深以外は同一条件の実験での最 大洗掘深さの時間的変化を比較した一例 が 図一19である. 下流水深が小さくて も間久的洗掘現象が現われない間の最大 洗掘深さの時間変化は下流水深に無関係 であるが，間欠的洗掘現象が発現すると 最大洗掘哚さの増加速度は極端に小さく なっている.

段落固定床実験によると噴出流の弯曲 
方向が変わる条件は境界面の幾何学的条件のみで決まる が，下流水深が一定である間久的洗掘で最大洗掘深さが 増大していくのは, 洗掘穴下流の砂堆部を流下寸る間の 損失水頭が大きくなっていき, その水頭だけ噴出流の弯 曲方向を規定する噴出孔付近の水位が上昇するからであ る.

無次元時問 $\tau=u_{0}^{2} / s g d \cdot u_{0} t / B_{0}=10^{7}$ における最大洗掘 深さ $D / B_{0}$ を下流水深 $H / B_{0}$ に対して描いたのが図一

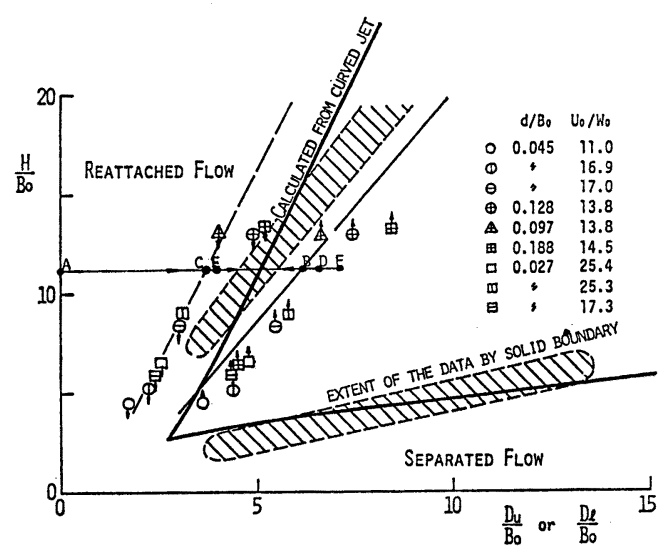

図一18 間欠的洗掘の発生限界と弯曲喷流の変流限界 との比較

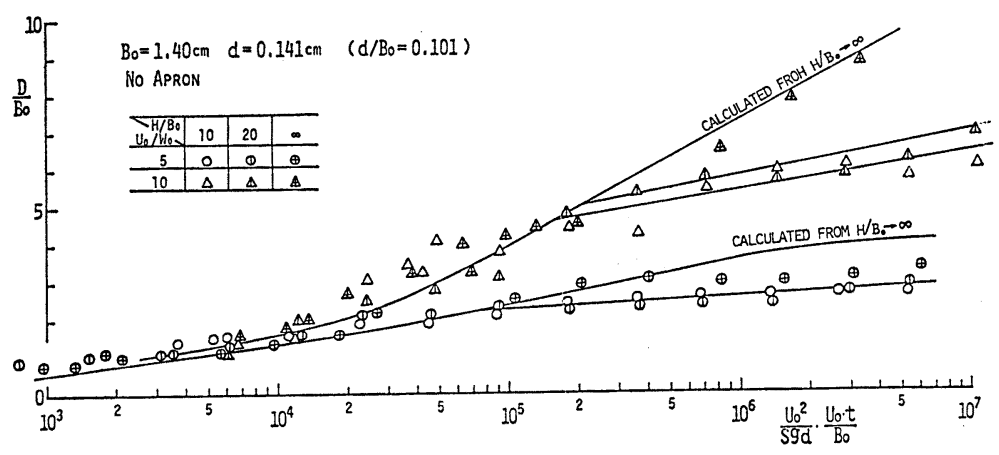

図一19 最大洗掘深さの時間的変化における下流水深の影響
20 で四中の実線は 図一17 の間欠的洗掘の発生限界であ る $I_{e} / B_{0} \sim H / B_{0}$ の直線である. 直線の左側領域で間欠 的洗掘がみられ, 下流水深が小さいほど最大洗掘深さは 小さくなっている.一方, 間欠的洗掘現象がみられない 直線の右側領域での最大洗掘深さは下流水深に無関係で ある。

\section{8. 結語}

以上, 二次元水平噴流による洗掘と流れに関する詳細 な実験を行い, 洗掘過程を初期, 中期および後期洗掘に わけ, 以下のように洗掘穴内の流れおよび砂移動をモデ ル化して理論的な検討を加えた.

初期洗掘においては水平壁面噴流流れの特性を用い， 中期および後期洗掘における洗掘穴内の流れは弯曲噴流 およびそれによる壁面噴流の流れで表わし, 洗掘砂面上 の流れの特性を最大洗掘深さで表示した.

中期洗掘においては洗掘穴下流側斜面での流れのはく 離の影響, 後期においては噴流の動摇による間欠的崩落 を導入して洗掘穴内の砂移動をモデル化した.

これらを非平衡状態での砂移動による河床変動の基礎 式に用い，洗掘過程を追跡した.

解析においては流れのはく離が砂移動に及ぼす影響な どにかなり粗い仮定が導入され ているが, 計算結果は最大洗掘 深さと無次元時間との関係およ び洗掘形状などの実験結果とか なりよく一致して, 噴流の洗掘 穴方向への弯曲と壁面に再接触 後形成される壁面噴流が洗掘に きわめて重要な役割をもつこと が示された.さらに, 実用上重 要な下流水墚が浅い場合には, 噴出流が交互に上・下方向の弯 曲を繰返す間欠的洗掘現象の発生限界および最大洗掘深 さなどへの影響を系統的な実験によって明らかにした。

以上得られた結果は，水門やカルバートなどの下流部 に扝ける局所洗掘を合理的に軽減するための基礎資料と して応用することができよう.

最後に本研究の遂行にあたり種々ご教示をいただいた 九州大学・椿 東一郎教授に哚甚の謝意を表する.また, 実験·計算に際して多大なる協力をいただいた亀田芳満, 林 健二郎, 山本規夫, 松尾真治, 松下浩之, 前田和雄 の諸氏に感謝の意を表する.

\section{参考 文 献}

1) Laursen, E.M. : Observation of the nature of scour, Proc. 5th Hyd. conf. State Univ. of Iowa, 1952. 
2）岩坦雄一・土屋義人・今村正孝：水門下流部に扔ける局 所洗掘に関する研究, 京大防㷋研究所報, 第 8 号, 1965.

3) Tsuchiya, Y.: On the mechanism of the local scour from flows downstream of an autlet, Proc. 12th Hyd. Conf. Colorado State Univ., 1967.

4）斎藤 隆 : 二次元乱流壁面噴流に関する 研究, 土木学会 論文報告集，第 264 号, 1977 .

5）斉藤 隆：境界の影響を受ける二次元噴流の特性, 土木 学会論文報告集, 第 164 号, 1969.

6）斎藤 隆・赤司信義・亀田芳満：衝突および再接触噴流 による壁面噴流, 山口大工学部研究報告, 第 28 巻, 第 1 号, 1977.

7）椿 東一郎・斎藤 隆: 流れによる Sand wave の発生限 界, 九大工学集報, 第 40 巻, 第 5 号, 1967.

8) Einstein, H.A. : The hed load function for sediment transportation in open channel flows, U.S. Dept. Arg. Tech. Bull. 1026, 1950.

9）椿 東一郎・斎藤 隆：突堤による河床の洗掘について, 山口大工学部学報, 第 13 巻, 第 1 号, 1963.

10）篠原謹爾・椿 東一郎：河床砂䃯の移動機構に関する一考 察, 九大応力研所報, 第 10 号, 1957 .

11）土木学会編 : 水理公式集, 46 年度改訂版, pp. 205, 昭和 46 年.

12）矢野勝正 - 土屋義人 - 道上正規 : 砂碗の流送機構の確率 過程としての特性について, 京大防災研年報, 第 11 号 B, 1968.

13）土屋義人：混合砂碗の限界掃流力に関する研究，京大防 災研年報, 第 6 号, B, 1962.

(1978.1.30 - 受付) 